\title{
Spaces and Journeys in Ernesto Daranas' Conducta: Che or Martí?
}

\author{
Yanira Angulo-Cano \\ Eckerd College \\ anguloy@eckerd.edu
}

\begin{abstract}
In his film Conducta (Behavior 2014), Ernesto Daranas portrays the ethical and physical challenges of an aging teacher, struggling to improve the lives of her students, not just within the classroom setting, but also in their family and social spheres. Thus, in response to a top/down social structure where an unseen government exerts economic and political pressure on schools and families in crisis mode, Daranas proposes model redirecting away from Ernesto Che Guevara and back toward José Martí as a pedagogic strategy for modulating conduct expectations of elementary school children. However, because government censorship sensitizes the spoken word, the filmmaker is careful to avoid negative repercussions by letting markedly visual elements of his mise en scène reveal indiscreet, if not outright subversive views of home, school, and cityscape. Also, through a recurring wandering narrative format, Ernesto Daranas conducts a political inquiry analogous to how Radicant aesthetics exercise wandering narratives.
\end{abstract}


Keywords: diegetic sound; framing; mise en scène; montage; palestina; Oriente; Our Lady of Charity; reconfiguration; Santería; Radicant aesthetics; wandering narrative

\section{Resumen}

En su filme Conducta (2014), Ernesto Daranas destaca las pruebas éticas y físicas de una maestra que según envejece redobla esfuerzos por mejorar la vida de sus alumnos, no sólo dentro del aula, sino también en ámbitos familiares y sociales. Por lo tanto, como respuesta a una estructura social hegemónica, donde un invisible gobierno ejerce presiones económicas y políticas sobre escuelas y familias afectadas por la precariedad, Daranas propone substituir el modelo de Ernesto Che Guevara con el de José Martí como estrategia pedagógica para modular las expectativas de conducta para niños en escuela primaria. Sin embargo, debido a que la censura gubernamental pone en riesgo el libre uso de la palabra, el cineasta evita repercusiones negativas valiéndose de elementos marcadamente visuales que, en su puesta en escena, revelan condiciones subversivas en hogar, escuela y ciudad. Además, gracias a un ambulante formato narrativo, Ernesto Daranas ofrece al espectador una investigación política análoga a la que profesa la estética radicante.

Palabras clave: composición; estética radicante; montaje; narrativa ambulante; Nuestra Señora de la Caridad; Oriente; palestina; puesta en escena; reconfiguración; santería; sonido diegético; toma de cámara

uban cinematography requires a certain degree of expertise in reading tea leaves. One case in point is the film Conducta (Behavior), directed by Ernesto Daranas and released in 2014, which deals with classroom "rules of conduct" affecting two elementary school children. In Conducta, Daranas portrays the ethical and physical challenges of an aging teacher, Carmela (Alina Rodríguez), as she struggles to bring back from reform school Chala (Armando Valdés Freire), one of her troubled boys. While Carmela is first tested by objections from Marta (Miriel Cejas), a younger colleague and then the 
principals of regular and reform schools Mercedes (Idalmis García) and Carlos (Tomás Cao), the veteran teacher is eventually able to enlist their support. At the same time that Carmela recruits allies, she makes enemies among district school officials, who in turn fear political repercussions from unnamed, higherup government functionaries. Cubans in the island do not need tea readings for figuring out Daranas' message: government policy controls children's future.

Despite the film's narrative emphasis on the institutional and state structures that exacerbate the many troubles facing the youth for whom Carmela advocates, this article proposes that Conducta's agenda is not so much enjoined to an anti-government political statement, as it constitutes a plea for redirecting school conduct expectations away from the ideas of Ernesto Che Guevara and back toward those of José Martí. In addition to tracing the ideological movement toward Martí, I argue that the camera's meandering critical eye wanders from home to school and throughout a decaying Havana, moving spectators to share the filmmaker's critique of institutional rigidity and to evaluate the government's official internationalist policy against their own calamitous conditions. This kind of urban wandering is analogous to how Nicolas Bourriaud characterizes ambulatory narratives in his critical text The Radicant (2009). I maintain that Bourriaud's "Radicant" aesthetics are analogous to how Daranas conducts his own roaming political inquiry in support of creating distance from Che's and toward Martís vision for Havana and, by extension, Cuba.

\section{Conducta's Film Text}

Cuban film directors have had to exercise caution when attempting to demystify national heroes. When Ernesto Daranas dissects dysfunctional families, schools, neighborhood church and other barrio settings, he runs the risk of being perceived as challenging the Cuban Revolution socio-political system itself. Tomás Gutiérrez Alea, Cuba's most recognizable film director had 
already charted a course for navigating such treacherous waters, especially in his last two films, Fresa y chocolate (Strawberry and Chocolate 1993) and Guantanamera (Girl from Guantánamo 1995). In his films from the 1990s, Gutiérrez Alea exposed socio-political restrictions on non-traditional gender roles and denounced female inequality within the family.

Despite his reputation as a pioneering figure in the filmic production of the Cuban Revolution and his reputed personal relationship with Fidel Castro, viewers quickly surmised his preference for narratives that played up the Revolution's achievements, while his mise en scène favored images of precariousness and official mismanagement. Of course, the audience was left with the task of contrasting the former with the latter. This strategic approach provided Gutiérrez Alea with a less exposed subtext for questioning politically sensitive subjects, such as bureaucratic inefficiency, machismo, and the precarious cityscape of the once elegant city of Havana.

Following Gutiérrez Alea, other film directors also offered useful tactics for avoiding government backlash. Rudy Mora's Doble juego (Double Game 2002) tactically rejects relocation to Miami for two girls suffering physical and emotional trauma at the hands of family and school mates, while allowing the camera to present visions of concurrent moral decay and persisting machismo. Similarly, Ian Padrón's Havanastation (2011) is a play on words that recalls the game platform, PlayStation, and its connotation inside Cuba of economic privilege for those empowered with access to the outside "capitalist" world. In this film, Padrón attempts to balance a visual narrative of unequal family access to children's toys with an unrealistic, but politically correct, pledge of solidarity from one privileged family to a less fortunate one. Given his predecessors' success in escaping overt government censorship, it is logical to assume that Ernesto Daranas would follow in their footsteps.

Throughout Conducta, Daranas shows precarious urban settings with ruinous buildings, streets and poorly dressed people, as in an early flowing scene 
where Chala attends to his pets (01:43) and hurries to join Carmela on their way to school. Other than pigeon cooing and dog barking, the humming of a far-away engine and the ringing of a nearby bicycle bell, there are few urban, or industrial sounds, no diegetic music or-aside from Carmela's and Chala'seven human voices. Daranas' opening street view feels disorienting, as it shows pedestrians silently and expressionlessly walking, in very close proximity, all around Carmela and Chala (e.g. see Fig. 1). What makes this and other scenes peculiar, is the director's framing of walkers' out-of-focus, half-faces and body parts obstructing the viewer's line of sight of the teacher and student (02:50).

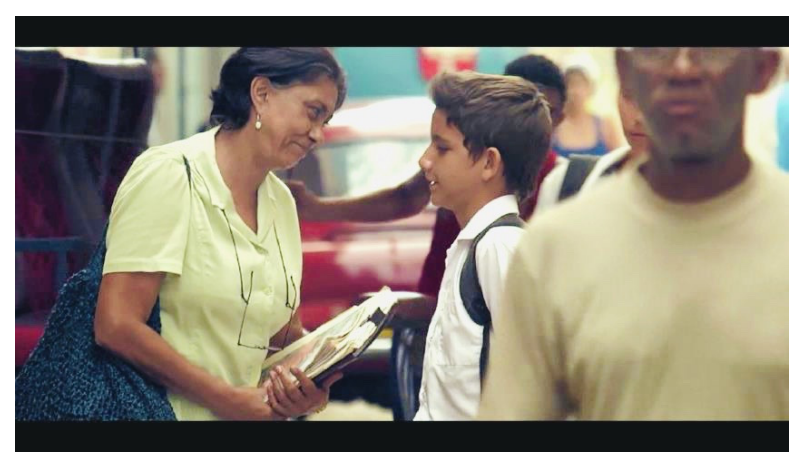

(Fig. 1). Carmela and Chala about to leave for school. Half-face framing of pedestrians creates viewer's curiosity (Conducta 02:50).

Since framing is a tool for calling attention to something of importance, which the half-face/body-part frames do not warrant, it must be assumed that this is Daranas' way for stimulating viewer's curiosity: Where are these silent, expressionless people going to? Is their fragmented physical presentation symbolic of their broken lives? Framing, in addition to montage editing and Alejandro Pérez's camera angles, together decode the director's implicit institutional censure. 


\section{Politics in the Classroom: Che vs Martí}

As many of the above-mentioned Cuban films remind us, questioning family relations can be politically sensitive in Cuba, and so Daranas is careful to avoid potential censorship of the spoken word, letting markedly visual elements of his mise en scène reveal indiscreet, if not outright subversive views of home, school, and cityscape.

Take for example a morning routine enacted in a drab school patio where raucous children go through a well-rehearsed collective chant: "Llamados por el comunismo, iseremos como el Che! [When Communism calls, we will be like Che!]" prior to transitioning into Carmela's classroom (42:03). Conversely, in the veteran teacher's classroom there are no graphic or spoken references to Che Guevara, but instead, her classroom features a poster of a school-age José Martí (58:09). In her morning routine, with a José Martí quote-“Patria es humanidad [The Nation is kindness] "-written on the blackboard at her back, Carmela honors Martī's standing in the national mythology by asking her students opinion questions about his philosophy: “¿Quién me va a comentar la idea martiana de hoy [Who is going to comment on Martî's idea for today]?" Her question elicits significant student commentary. In a close-up shot, a boy links Martí's broad humanistic concept of the nation to his uncle living abroad; after years residing in the United States, he still identifies himself as Cuban.

With this student's politically innocent comment, Daranas pushes back on Che's antagonistic political agenda (45:45). While Che-inspired slogans may provoke laughter and raucous behavior, Martî's image and words soothe and prepare the children for academic enrichment. For multigenerational Cubans, Martí occupies the highest place of honor in the national mythology, therefore, when Carmela's classroom features Marti's school-age picture, his quote of the day written on the board, and the teacher eliciting class commentary on the quote, it represents Daranas' intent to reenergize Martî's presence in the classroom with arguably his best-known and most applicable statement 
for the classroom, "Los niños son la esperanza del mundo (Children are the world's hope)." It appears in his prologue to La Edad de Oro (The Golden Age), a children's magazine he published in New York City for the benefit of preteen children of Cuban and Spanish American origin (La Edad de Oro 10a). The statement stresses developing in children a thirst for knowledge and improving communications between boys and girls as key for maintaining/ improving economic and human development (10b). This magazine is made up of poems, children's tales, short essays on mythical and historical figures, and current events that Martí considers helpful in the ethical development of children. Indeed, a long shot of the back wall of Carmela's room reveals a front cover facsimile of the magazine (04:44).

In contrast with Che Guevara's uncompromisingly bellicose rhetoric, Martí calls on Cubans, children, and grown-ups, for friendly engagement with both friends and rivals through his white rose metaphor: "Y para el cruel que me arranca / El corazón con que vivo, / Cardo ni oruga cultivo / Cultivo la rosa blanca [And to the cruel one whose blows / Break the heart by which I live, I Thistle nor thorn do I give / For him, too, I have a white rose]" (Versos sencillos / Simple Verses 104-105).

José Martî's message can be summarized as promoting social harmony and tolerance of opposing views. Both ideas are seared into the collective memory as basic components of Cuba's national allegory. From Jorge Mañach's laudatory book title, Marti: Apostle of Freedom, to Fredric Jameson's "Third World Literature in the Era of Multinational Capitalism," José Martí has been recognized as Cuba's preeminent foundational national figure (81). Very indicative of his status is the fact that Cuban currency both before and after the Revolution has carried his likeness in one-peso bills and coins. Interestingly, although Martí called for armed insurrection against Spain, he was careful to distinguish between the Spanish colonial government and the Spanish people. As a matter of fact, not just in "Poema XXXIX," but also in "Poema VII," his 
message is nuanced toward reconciliation with all Spaniards (Versos Sencillos / Simple Verses 16-17). This poem is Martî's version of the biblical "turn the other cheek" doctrine. It is known arguably by every Cuban since it is often required reading and memorization assignment in elementary school. For Daranas, Cuban children need to learn the art of compromise and non-violence.

To most viewers of Conducta it would seem clear that Martî's message of hope in humanity sharply contrasts with Ernesto Che Guevara's uncompromising fighting words to Cuban youth wanting to join international work brigades, "we saw no way out for the Cuban people other than the voice of guns... we must firmly unite around those rifles" (Che Guevara Talks to Young People 59); or encouraging Young Communists to emulate the Bay of Pigs Cuban militia, many of them children, "who were manning cuatro bocas [four mouths, anti-aircraft weapons with four barrels]... defending their homeland from Yankee invaders" (Guevara 111). In the end, the Martíinflected national mythology of tolerance and reconciliation allows the average Cuban viewer to detect a dissonance in Guevara's inappropriately bellicose message for elementary school children.

As a ringing bell heralds the end of the school day, Carmela reminds her students of their homework assignment-a free-topic essay, written from a first-person perspective-which draws a disingenuous question from Chala about the meaning of "I." Carmela responds to this minor challenge to her authority with some blackboard work, a little humor and a measure of discipline (04:15).

While addressing the class and moving closer to Chala's desk-a low-angleshooting camera at her back-she casually drops her right hand near Chala's leg and playfully smacks him with a ruler, eliciting loud reactions of exaggerated surprise among the students. Carmela then immediately turns around-the camera now in a normal line-of-sight angle-and, while she walks back to the front of the class, her left hand caresses the boy's hair (04:38). The difference 
in the two shots is important in determining her disciplinary philosophy. With one hand, she made sure that students could see her symbolic punishment, while with the other she demonstrated how much she appreciated Chala's presence in her classroom; Daranas tacitly proposes turning to a Martí-inspired, humanistic pedagogy to deal with classroom conduct.

\section{Wandering Narratives}

Daranas appears to reject Che's message of sacrifice or martyrdom for the revolutionary cause, but given his awareness of the official censorship obsession with the spoken word, he lets his camera techniques do much of the talking, creating a critical eye that wanders from home to school throughout a decaying Havana. In doing so, spectators are moved to evaluate the government's official internationalist discourse against Cuba's real-life precarious conditions. This kind of urban wandering is akin to Nicolas Bourriaud's notion of ambulatory narratives in The Radicant (2009).

The Oxford Dictionary reveals that the adjective radicant describes how some plants can root from "a stem or fern frond: producing (...) roots or rootlets." This is a useful image to understand Bourriaud's concept of wandering narratives, stories that privilege the act of rummaging, the unsystematic experience of exploration as a kind of "political inquiry" into the city (100); where the journey not only "has become a dynamic art form in itself" (107), but simultaneously represents "a compositional principle" (113).

In such narratives-suggestive of the movements of Walter Benjamin's flâneur-characters move about offering visual commentary on the precarious social, political and physical conditions affecting the modern city (Bourriaud 76). Radicant aesthetics are analogous to the ways in which Daranas conducts his camera's wandering political inquiry-one that move's away from Che's revolutionary and bellicose rhetoric and toward Martî's conciliatory vision for Havana and the Cuban nation. Conducta exposes a society that constantly 
invokes solidarity with the marginalized, but often falls short of practicing it. It does so by showcasing Carmela's exceptional classroom as an oasis of affection and academic rigor, from which her students leave bound for home, navigating precarious urban landscapes in their barrio (e.g. see Fig. 2). As a product of their comings and goings, the spectator is invited to reflect on a narrative that serves as counterpoint to that offered by official school policy, which mandates children's expulsion without providing effective alternatives for continuing their education.

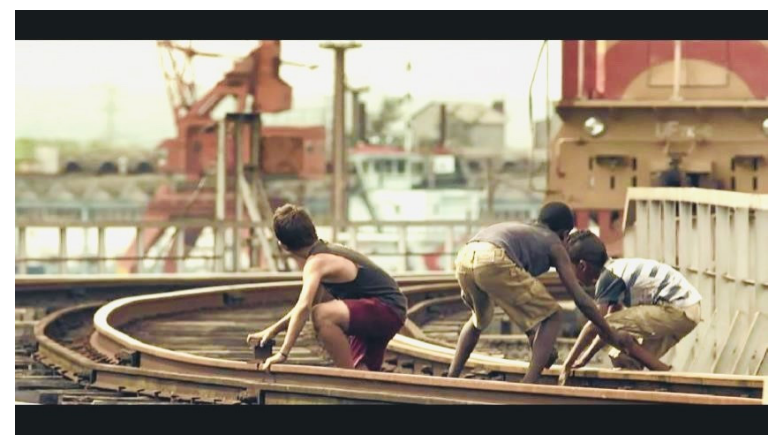

[Fig. 2]. Chala and friends using locomotive to flatten metal pieces. People nearby are oblivious to their dangerous activities (Conducta 18:39).

One good example of this is Chala's wandering through his Old Havana neighborhood, contemplating his home/school troubles and the threat to send his dear friend, Yeni (Amaly Junco), back to the island's Oriente region. His steps-the framing of Chala's legs walking over the seawall (1:21:05) - take him back to the area across from Morro Castle where he previously undertook a swimming competition challenge. However, the montage now serves to represent Chala's wandering inquiry-if, given Chala's age, the viewer is willing to suspend disbelief-about a city unable to offer these children much needed 
educational and social service assistance.

As Chala stands at the water's edge, across from Havana's iconic colonial fortress, all he sees is the Morro's rocky base, part of Daranas' framing of a green buoy marking the harbor's entrance/exit. This puzzling scene is followed by an upward camera angle showing a taller image of Chala standing at the seawall, deep in thought. His conflicted state of mind is then shown by a high camera angle, from the boy's line of sight, that lingers over the churning sea water below his feet (1:21:14).

Does Daranas pique audience curiosity towards a specific goal-Chala toying with the idea of fleeing the island? Daranas frames his political inquiry into the Havana cityscape by showing his characters sorting their life choices through unsystematic explorations of their environment, rich in Radicant symbols-here an exit channel to the ocean, snaking railroad tracks elsewhere (18:24) —and enlisting audience humanitarian desires to improve the children's lives.

\section{Pyramid Structured Narrative}

Conducta is a film about an urban center with a pronounced top-down structure, where an unseen, unmentioned government hovers above and brings pressure to bear on schools and families through law enforcement officers, school administrators and teachers. It tells the story of families in permanent crisis-mode, affecting mainly two "nuclear" families (Chala's and Yeni's) but less so Carmela's extended family (Orlandito's).

The first family is Chala's, composed of his parents, who are unmarried and live separately: Sonia (Yuliet Cruz) and Ignacio (Armando Miguel Gómez); the second is Yeni's, only including Pablo (Héctor Noas), her father; the third is Orlandito's, Carmela's grandson (Oscar Rill), made up of her unnamed daughter and son-in-law (Joanna Gómez and Ariel Albóniga Carmona). Whereas the make-up of the three families includes one named child, the same cannot 
be said about the parents. Also significant is the suggestion of a fourth family - that of the terminally ill and seemingly abandoned Camilo-by which Carmela's protective role becomes even more evident. In contrast, afraid of government intervention, the upper levels of the school administration insist on the enforcement of residency status and school conduct policies, regardless of their impact on students' needs. In the case of Chala, his misbehavior is rather common for his age, as in cases when he mischievously removes letter "T" from a sign designating his classroom as "SEXTO A" [Sixth Grade A]," and wolf-whistling Marta upon her arrival as temporary substitute for Carmela; however, what triggers his send off to reform school is when Marta catches other boys playing with Chala's cards and demands that they be handed over.

Chala refuses to do so because he was not playing with them. While the young teacher seems puzzled by Chala's behavior, she does not attempt to understand his refusal for accepting blame. However, Carmela's later admonition to Marta also reflects Martî's teachings: "Si quieres un delincuente, trátalo como un delincuente [If you want a law offender, treat him like an offender]" (43:32).

As far as Yeni is concerned, her case presented a serious threat to school administration, and perhaps even exposure to criminal prosecution. For them, the sweet, hardworking, well-behaved Yeni is "guilty" of two basic infractions that could bring about unwanted attention from higher ups. First, the girl and her father have moved into a railroad-depot shack in Havana, in violation of residential and school restrictions. Carmela not only knows this fact; she allowed her father to register Yeni illegally in school. For his part in this irregular situation, Pablo has managed to keep his daughter and himself in Havana by paying bribes to the police. However, increasing precariousness of life in the capital has made it progressively more difficult for Pablo to continue paying bribes.

Yeni's second and more serious infraction relates to her cancer-stricken 
classmate, Camilo. During the boy's illness, classmates come to visit him at the hospital, but except for Carmela, Daranas does not show family or school personnel visiting or otherwise involved with the terminally ill boy. Therefore, when Camilo dies, only Carmela and his classmates are grief-stricken. Carmela's class is interrupted with the tragic news and, while she tries her best to soften the blow, the camera starts framing individual student faces in various degrees of sorrow. In a close-up shot of Yeni's face, her tearful eyes deepen Chala's own sadness, soon followed by a partially out-of-focus, shot reverse shot sequence for capturing their pain-sharing tears (46:51).

It is then that Yeni opens her notebook, takes out a lithography of the Virgin of Charity, goes to a poster board displaying clippings of national heroes, and places the Virgin's image on it. Daranas framing calls attention to the image by showing it covering part of a José Martí quote. It can be identified as "Una escuela es una fragua de espíritus" [Schools forge character], but it does not supersede Martîs multiple representations in Carmela's classroom. Though it may cause viewers' reflection and concern about its place in a public school classroom, Carmela's support for the girl's action points to Daranas' real message: Yeni's right to express her sorrow, especially when risky, is proof of her growth in character (47:06).

It is worth explaining that if the position of the Catholic Church on the island already was weak prior to the 1959 Cuban Revolution, the new secular socio-political order brought about a more intensive scrutiny of any classroom activity that might be associated with the church. Displaying religious paraphernalia became ideologically delicate. Therefore, when the educational authorities learned about the religious card, they demanded its removal as a condition to keep Yeni in school. This episode of the lithography of the Virgin of Charity forces Carmela to respond to the reverberations from decades of religious prohibitions. The residual reproduction of control persists through the actions of her superiors within the educational system. 
For Carmela, the crisis affecting Yeni and other students has deep personal repercussions beyond the classroom. Daranas' montage intertwines her speech to school authorities with student classroom activities, thus, when the student crisis over Camilo's death erupts, Carmela already had presented-through a series of medium close-up shots-her personal connection to the Virgin of Charity. She states: "Mi abuela era nieta de esclavos [My grandmother was a granddaughter of slaves]" (03:13); "No se lo creía el día que le enseñé mi título de maestra. Se gastó cinco pesos para un cuadro que colgó debajo de la Caridad [She could not believe it on the day I showed her my teaching degree. She spent five pesos for a frame that she hung under the Virgin]" (03:18); and "Ahí está todavía [It is there still]" (03:29).

As a professional, Carmela identifies with the Virgin's attribute as a savior of children in need. As an Afro-Cuban, it allows her to honor her ethnic heritage. She is not willing to compromise her ethics by appeasing bureaucrats afraid of losing their own jobs. As she sees it, her foremost responsibility is to guide her students' humanistic education in the context of the death of a fellow student.

Carmela also is aware of why Yeni was so deeply affected by Camilo's death. As the girl told her, Camilo had been the only classmate that never called her by the derogatory term palestina, slang for mocking people from the Oriente region in the East of Cuba, whose geographic isolation, as well as their location in the "Orient", assimilates them to Palestinians, in the metropolitan popular imaginary. His kindness towards her also included giving her the religious card and taking her to church for the first time.

\section{Radicant Reconfiguration: The Family}

While Carmela's family is allowed to migrate to the US, Yeni's family hopes for a better life in Havana are dashed when they are forced to return to 
Oriente. Such discrepancies about families treated unequally can be both hard to explain and politically risky. Daranas chooses to expose them indirectly by means of what Radicant esthetics call reconfiguration, a technique for evaluating how something changes over time after certain parameters are reworked or reconfigured (Bourriaud 135).

Thus, in the scene where the boy comes face to face with his disheveled mother coming back from an all-nighter, clearly under the influence of drugs/ alcohol, the camera tilts up, showing Sonia's back as she climbs the stairs with unsteady steps, while Chala is coming down from above her (02:10). The low angle shot reconfigures the traditional mother/son roles when sending a child to school, not just by showing the boy towering over the mother, but also by empowering Chala's decision-making. His position of authority is reinforced by his words to her- “Te dejé café en la cocina [I left coffee for you in the kitchen]" (e.g. see Fig. 3) -and by a medium shot of her dejected look silently leaning her back on the wall, as the boy hurriedly passes her on his way down to the street $(02: 18)$.

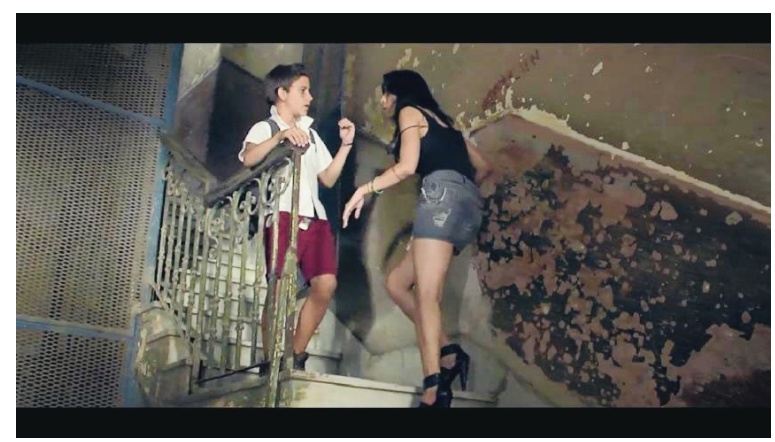

(Fig. 3). Chala leaves for school while Mom returns from an all-night out. In a reversal of roles, Chala offers advice for Sonia (Conducta 02:18). 
In Conducta, most adults hold the opinion that Chala is a mischievous boy, while Carmela disagrees. She knows Chala's home situation and tolerates his antics in her classroom, but she is more than willing to offer him the guidance that no other adult can provide at school or home. She knows that Chala is maturing exponentially as he is forced to assume, within his family, grown-up roles and new models of conduct. Indeed, his responsibilities include those of housekeeper, by keeping track of the electric bill (06:23); home provider, by earning money by taking care of his father's pit bulls and raising pigeons (26:53); caretaker of his drug addicted mother, by cooking and feeding her (05:30) and father-figure, by actively curtailing her negative behaviors that had sent her to the hospital (1:35:10).

\section{Radicant Reconfiguration: The School}

Another entity subjected to reconfiguration is the school, specially the reformtype to which officials send Chala as their solution for his rebellious behavior. They are aware of the boy's home situation, and yet, despite its institutional shortcomings, they persist that its environment would be beneficial for the boy. Daranas camera offers a different opinion.

From a high camera angle, the film shows what must have been an old colonial mansion with rooms opening to a Mediterranean garden, but now transformed into a concrete-tile covered floor (29:30). It is over this surface that the children play soccer and engage in rowdy/violent behaviors. It resembles more a prison exercise yard than a place for academic learning (30:20).

The film does not show any academic activity in the reform school, but instead something of an overcrowded holding pen. Therefore, soon after Chala arrives, he is forced to fight a school bully, a scene that leaves the audience to surmise that, at the reform school, violence may be the most commonly used "pedagogical" tool (30:20).

At first, only Carmela dares to challenge Chala's reassignment. She 
confronts her substitute, Marta, among others, arguing that the experience will not be good for the boy's future. As a teacher of long tenure, Carmela reminds Mercedes and Carlos that they were her students too, and that as children they were no better than Chala. She criticizes her colleagues for being more concerned with protecting their interests, vis à vis the higher ups in the school system, than living up to their professional ethics. Furthermore, she pledges to curtail Chala's negative behavior and does so with a combination of love and a firm hand. Ultimately, after an exasperated Carmela undertakes her unilateral rescuing of the boy from the reform school, their relationship grows.

While Carmela's interventions suggest a measure of improvement in the boy's family and school dynamics, the same cannot be said about Yeni. Despite the old teacher's efforts, and Yeni's excellent classroom behavior, the girl cannot stay at school because of her illegal status in Havana. Carmela's failure in this task turns on the Virgin of Charity holy card.

To Cubans, believers and non-believers alike, the traditional representation of La Caridad [Charity], as she is informally known to Cubans, is well known as the nation's spiritual protector, familiar in iconography that depicts her hovering and miraculously protecting three boys in danger of capsizing while crossing a stormy Bay of Nipe circa 1612.

For Conducta's viewers, it would seem surprising, given the long-standing exclusion of religion from the classroom, for the nation's Patron Saint to play such a prominent role in this film. Daranas uses the Virgin's display in Carmela's classroom to underscore what he sees as politically charged school hypocrisy toward religion; that is, while the government leadership generally has kept the Catholic Church, and its mainly Caucasian, middle-class followers at arm's length, it arguably has allowed a generally more flexible policy toward the mainly Afro-Cuban and lower-class Santería followers. Consequently, top levels in Daranas' pyramidal narrative exert strong anti-Catholic compliance pressure on lower administrators and teachers. However, Carmela's ability to unmask 
their hypocrisy is on display too, as she makes school officials acknowledge their own Santería icons hidden in plain sight in their offices.

Once again, this is part of Daranas' indirect style of dealing with politically charged subjects. Carmela never addresses directly the issue of religion in the Cuban classroom; instead, she argues that, out of respect for the girl's feelings, if Yeni placed the religious card on display, then it is up to the girl to remove it. Carmela does not have to acknowledge the icon's traditionally accepted protective message; it serves as visual counterpoint to official school policy promoting solidarity with the oppressed peoples of the world.

Daranas suggests that no matter how often the slogan "Seremos como el Che" is repeated in schools throughout Cuba, it does not address the real needs affecting Chala and Yeni. Contrary to the Virgin's mythological protective message, seared into the collective memory, children like them are left unprotected from bureaucratic waves pouring down from the top of the social pyramid.

\section{Safe/Unsafe Spaces}

Conducta is a reform-minded film about children caught in a sociopolitical crisis affecting home and school. As a first corrective step, it proposes returning to José Martî's philosophy for rearing children, but it also seeks to identify those spaces where adults and children can safely maximize their energies in the pursuit of happiness. Carmela's classroom is Daranas' safest place of choice. The room looks typical of traditional classrooms, with blackboards, poster boards, tightly packed student desks and a wide teacher's desk. Walls and window shutters need paint, but students are wearing clean uniforms. Nonetheless, what makes this room stand out is the framing of two poster boards, one on either side of a rear classroom corner, slightly above and beyond an array of students that have turned around to face Carmela, standing at the back of the room. 
Among the two boards spectators can make out seven visible likenesses of José Martí at different stages of his life, including one where Martí is accompanied by two other $19^{\text {th }}$ Century Cuban heroes who fought for independence from Spain (1:34:39). However, due to the liberal use of montage technique in Conducta, this scene has an earlier, ten-minute start in the film.

It begins with an medium close-up shot of Yeni and Chala attentive to Carmela, who questions Yeni: “¿Tú te acuerdas la razón por qué pusiste la estampita en el mural [Do you remember the reason why you placed the religious card on the display board]?" Apparently, a rhetorical question, since she immediately fires a general question to the class: “¿Alguien vio algo de malo en eso [Did anyone see something wrong in that]?" Then, while a medium close-up shot of Chala, Yeni and two other students shaking their heads indicate a negative response, the camera shifts to a long shot, from the back to the front of the room, showing all students directing their shaking heads toward Carmela. It is worth nothing that while this exchange is taking place, the right edge of Daranas' frame is slowly revealing a large poster of a sitting, student-age José Martí that presumably may also be, symbolically, part of the class (1:33:24).

At this point, Carmela presses her students for a more substantial response: "¿Qué pasó entonces [What happened then]?" As expected, the two class leaders, supported by other students, are eager to offer their opinions on what they fear is behind Carmela's forced retirement. Daranas frames a back and forth of camera angles where Chala thinks is because she brought him back from reform school, while Yeni fears is because she placed the religious card. Carmela dismisses their concerns as motives.

Yeni asks Carmela, "Profe, ¿hay algo de malo que la estampita esté en el mural [Teacher, is there something wrong if the religious card is on the display board]?" (1:34:06), to which Carmela replies in the negative, but adds that what is important for herself is that everything should be as they, the 
students, think it ought to be.

However, not entirely satisfied with the discussion, Chala hints at the real problem, "Aquí nadie es bobo; uno no sabe si se mete en tremenda candela [Let's not fool ourselves; we don't want to get into the fire]," but he does not dare to express himself openly $(1: 34: 16)$. Note that, despite the day's lesson words written on the blackboard, "Constitución. Deberes y Derechos [Constitution. Duties and Rights]," their fear of unseen authority makes the children practice self-censorship.

Unable to put the matter to a satisfactory rest, a long shot shows Carmela walking to Yeni's desk, extending her hand, while asking the girl for the card (e.g. see Fig. 4). The camera then shifts around 180 degrees to show in a long shot Carmela silently walking back to the back of the room and carefully placing the card on the same spot where Yeni had placed it originally. She then turns around to face her students, straining to see the Virgin's card on the display board, and after a few seconds, she reminds them that it is time to check homework.

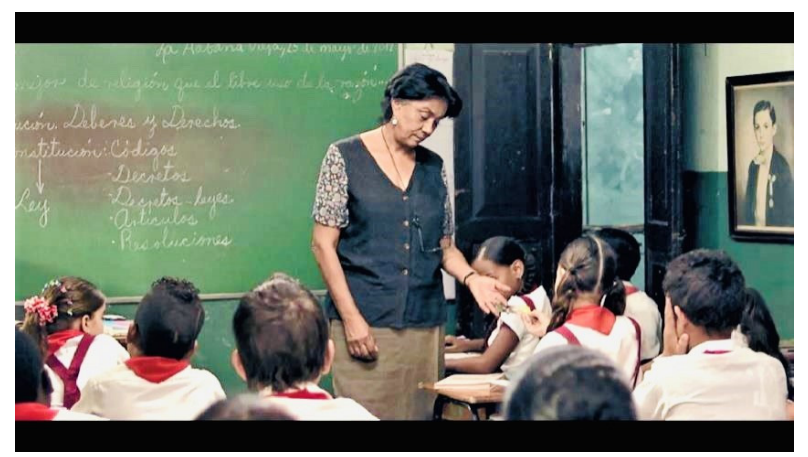

(Fig. 4). Carmela asks Yeni for the Virgin's lithograph. Her action is in keeping with the list of rights and responsibilities written on the board (Conducta 1:34:21). 
It is obvious that the restoration of the Virgin's lithograph must be assessed not so much from a religious point of view, but rather from Marti's ethical perspective for educating children as responsible citizens (1:34:32).

To bring home the impact of the safe and pleasant space, Daranas illustrate the very opposite: Ignacio's dog fighting pen, located above Chala's apartment and below the roof enclosure where the boy keeps his pigeons' coop.

A long shot across the dog-fighting room shows a dark green back-wall, adorned with once artistic red drawings of lines and circles. Decorations beyond recognition due to paint chips revealing earlier white or light green pigments, and because of lower-wall damage inflicted by removal of a tiled wainscoting. The viewer thus acquires an image of withered past elegance now further spoiled by a hanging car tire, left over construction pipes and a rough ladder made of misshapen wood planks. As the camera pulls further back from the green wall, it reveals an old wrought-iron veranda, another reminder of a bygone glamorous era, contrasting with a makeshift wooden corral-set between wall and veranda-where the actual fighting takes place (06:36).

At first, Daranas' camera angles push men to his mise en scène peripheryhuman arms and legs, exerting some control over the fighting-portraying through different angles and out-of-focus framing a life and death struggle for the combatants. Later, it shows men drinking, removing injured and dead dogs, while laughing or arguing over gambling loses (06:25).

While Ignacio pays Chala to feed and look after his dogs, Chala has developed feelings for one young canine. Chala has snuck up around the fighting ring and he has seen "his" young pit-bull win several fights. Ignacio admonishes Chala for being there during fights, however, the sermon sounds hollow since he pays Chala from the proceeds of the fights.

At the same time, the dog-fighting ring is not just a cultural entity useful for Radicant reconfiguration, but it already represents a reconfiguration 
of the long established Cuban gallería [cock fighting ring]. While the basic parameters remain the same-a life and death struggle between animals, combining the spirit of athletic competition with the greed of an exploitative money-making enterprise-the American import offers no improvement as it is not just as morally objectionable as the native Cuban blood sport, but also culturally alien.

It is in this context that Ignacio has been grooming the young pit bull to be his champion dog. He has selected very carefully the dog's opponents, and because of his handling, the dog has had a string of lucrative victories. Ignacio then asks Chala for all the money that he has earned in previous fights. He wants to gamble this money and his own on the next fight, only that unknown to Chala, he is betting on the opposing dog. For Ignacio this is an opportunity to make easy money at the expense of the life of Chala's dog and, while he provides support for the boy's household, he undermines his relationship with his presumed son. For Daranas, Ignacio's selfish action is not compatible with Marti's ethical upbringing of children. This is arguably the most negatively impacting experience in Chala's life, where he loses his good humor and his innocence by the dishonesty of his presumed father. Daranas' lens captures, in a close-up shot, Chala's anger on account of Ignacio offering to pay him his earnings from the fight (1:17:56).

To make matters worse, the dejected boy asks Ignacio point blank if he is his father. Daranas' lens reveals, in shot reverse shot technique, Chala's sadness upon hearing Ignacio's resounding "No sé [I don't know]" (1:18:30). Later, Chala will ask him again about his paternity and Ignacio will say, framed in a long pause and very sad voice: "Te juro que no lo sé [I swear to you that I don't know]" (1:38:23). This is, without a doubt, an intractable pain haunting both Ignacio and Chala. 


\section{Oppositional Strategy}

Daranas' anti-government, oppositional strategy is hidden in plain view from the film's very beginning: an out-of-focus, black and white, extreme close-up shot of an unrecognizable dark and squirming silhouette, while a loud and annoying high-pitch sound, presumably diegetic, is heard (00:29). Immediately, the camera abruptly shifts to a long shot of a clear, blue sky with pigeons flying against the background of Cuba's iconic National Capitol (00:35). As the lens pulls back to a medium close-up shot of the opening scene, it reveals Chala holding, shaking a pigeon and whistling (00:41).

After this strange and noteworthy start, Daranas adds further evidence that processing Conducta might present additional challenges. He does this by introducing a twist into the well-established shot reverse shot technique, which involves a long shot of a pigeon flying towards Chala's line-of-sight (00:44), followed by another long shot, from the bird's line-of-sight, as it flies towards Chala (00:47). This unusual application of the technique, normally reserved for human to human interaction, allows Conducta's viewers to share the pigeon's experience avoiding collision with a roof television antenna. By seeing what the bird sees, the viewer shares the feeling of first rapidly ascending over the obstructing antenna and then descending towards Chala's hands. At this very early point in Conducta's narrative, technical tricks may not be of much interest to most spectators, but Cuban audiences have had some experience interpreting post Revolution film texts. It is not a stretch for them to decode images of cages and chains, against the background of iconic government infrastructure, as implied symbols of government oppression.

For them, most intriguing of all is the manipulation of the shot reverse shot exchange between Chala and the pigeon. Cubans are aware that Fidel Castro not only pioneered television for "modulating" popular opinion, but also that he employed and controlled the medium intensely and assiduously; stations often carried Castro's four-to-six-hour-long speeches several times per 
month, as reported by the US Embassy in Havana (Castro Speech Data Base).

However, just when the audience is getting used to Daranas' oppositional strategy built on conspicuously visual/circumscribed dialogue characteristics, he surprises them with a daring incursion into explicitly critical dialogue.

It starts with Carmela in a classroom setting, addressing an unseen audience, at first presumed to be her students, although the tone and content really do not fit this notion (02:40). Although this will not become clear until later, Carmela is addressing an ad-hoc committee of former students, colleagues and school administrators carefully managing her retirement.

Carmela begins by refuting the reform school plan for Chala, objecting to the injustice that has sent Yeni back to Oriente and bypassing references to her retirement, except to indicate her satisfaction that Marta will stay on as her replacement. The anachronistic speech will unfold in fragmentary form throughout Conducta, without the viewer being aware that it takes place towards the very end of the film.

At a later segment of her rebuttal, Carmela is challenged by Raquel, the most powerful of the administrators, bent on forcing Carmela to either comply or retire: "A lo mejor ha sido demasiado tiempo [Perhaps it has been too long (Carmela's tenure)]." Carmela's response to this kind of coercion borders on the heroic: "No tanto como los que dirigen este país [Not as long as those that govern this country]" (51:04). This exchange-a shot reverse shot verbal duel between Carmela and Raquel—not only represents Daranas' most direct political statement in all of Conducta's dialogue, but also marks a daring departure from the more prudent use of his conspicuously visual film text, and it implies confidence in his chances for getting away with his character's words.

However, except for this brief risky exercise, Daranas returns to safe ground by displaying significant differences between indoor and outdoor settings. Whereas the former are mostly dark, depressing and restricting; the latter 
mostly appear in medium and long shots full of bright light, with bifurcating locomotive tracks suggesting journeys of opportunity and new life choices. Chala's open roof area provides a good example. When the boy releases his pigeons skyward-featured in the film's publicity poster-it represents not just the birds' irrepressible urge to spread their wings, but also a flight of destiny and self-fulfillment as may be interpreted by some in the audience.

Another outdoor scene involves a swimming competition challenge between Chala and a classmate across strong currents at the entrance to Havana harbor. This scene, complete with luminous underwater filming, may offer a coded and yet easily understood reference to maritime migration to Florida from the nation's most iconic port of entrance or, as would be more appropriate in the film's context, as the most direct port of exit to Miami.

However, even though outdoor sequences are bright and liberating, viewers soon notice that these scenes are continually interrupted. Pedestrians, cyclists, old American cars, newer police cars, buses, trucks, even locomotives, all get between the viewer's line of sight and the characters moving about (22:08 and 1:43:20). The spectator is constantly distracted, annoyed, even harassed to the point of wondering if they could represent negligence during editing.

Why these obstructions survived editing is more than a foolhardy question. Logic argues that because of their sheer number and spread throughout the length of Conducta, these "un-cuts" fit into Daranas' indirect strategy for opposing the status quo. Daranas' message must be that students, parents, teachers, school officials and even police officers labor under the weight of restrictions imposed by an unseen, but intrusive government.

The last few minutes of the film show Carmela and Chala walking back home, which constitutes the closing of the narrative circle of Conducta, that began at the outset of the film when they left from their respective homes to go to school. 
What is going to become of Chala? The answer naturally springs from their chit-chat and body language, suggesting a new beginning for the old teacher out of a job and the young boy in need of a grandmother's nurturing guidance. Also, even if Carmela is out of her classroom, the veteran teacher feels very confident that Marta is now occupying her classroom, looking after Chala's education, and carrying out her pedagogic mission inspired by Martîs philosophy.

\section{Conclusion}

As Cuba embarks on a new phase of economic and arguably political renewal, Ernesto Daranas has seized the opportunity to engage his viewers in this process. For him, continued beating on Che's war drum is no longer relevant, while Martís educational philosophy does offer an inspirational path for the nation's moral renovation. Daranas locates the plight of children in peril at the center of this discussion, while he circumvents government censorship by investing in a conspicuously visual film text to display and perform the crisis affecting children's lives, instead of inscribing it through a more explicit dramatic dialogue.

Moreover, Daranas narrative methodology makes use of a wandering, radicant, narrative format as a surreptitious tool for eliciting reflection on societal inattention to children in need. By including Radicant aesthetics for a creative exploration of healthier reconfigurations of school and family, Conducta performs a political inquiry that exposes a top-down social structure as incapable of solving the nation's many sociopolitical woes.

Ernesto Daranas' Conducta clearly is an indictment of the contrasts between home and school in contemporary Cuba, but ultimately its criticism reaches all the way up the social pyramid. In fact, while seemingly invisible to the camera's lens, the government's presence is felt through the hollowedout propaganda machinery of Che Guevara's internationalist political rhetoric, 
which contrasts with economic and social policies on the ground that would support stable homes and nurturing schools, but betraying their manipulative presence through repeated obstructions of the film's mise en scène.

Daranas gives top billing to an old teacher fighting negligent parents and school officials. However, he also turns family dynamics on its head by showing how a mischievous boy can rise to become something of a father figure to his morally challenged parents. In doing so, Enrique Daranas is able to breathe life back into Martî's old maxim: "Los niños son la esperanza del mundo."

Note on translations: except for bilingual sources, translations are my own.

\section{Works Cited}

Benjamin, Walter. Charles Baudelaire: A Lyric Poet in the Era of High Capitalism. Translated by Harry Zohn, Verso, 1983.

Bourriaud, Nicolas. The Radicant. Lukas \& Sternberg, 2009.

Castro Speech Data Base: Speeches Interviews Articles 1959-1996, University of Texas Latin American Network Information Center (LANIC), www.lanic.utexas.edu/ project/castro/1959/.

Conducta. Directed and written by Ernesto Daranas, performances by Armando Valdés Freire, Alina Rodríguez and Amaly Junco, RTV Comercial and Instituto Cubano del Arte e Industria Cinematográficos (ICAIC), 2014.

Doble juego. Directed by Rudy Mora, written by Olga Consuegra and Rudy Mora, performances by Mónica Alonso, Liety Chaviano, Corina Mestre, Raúl Pomares, Miriam Socarrás and Broselinda Hernández, Embajada de Cuba and ICAIC, 2002.

Fresa y chocolate. Directed by Tomás Gutiérrez Alea and Juan Carlos Tabío, performances by Jorge Perugorría, Vladimir Cruz and Mirtha Ibarra, ICAIC, 1993.

Guevara, Ernesto Che. Che Guevara Talks to Young People. Edited by Mary-Alice Waters, Pathfinder, 2000, www.pathfinderpress.com.

Guantanamera. Directed by Tomás Gutiérrez Alea and Juan Carlos Tabío, performances by Carlos Cruz, Mirta Ibarra and Jorge Perugorría, ICAIC, 1995. 
Havanastation. Directed by lan Padrón, written by Felipe Espinet, performances by Claudia Alvariño, Rubén Araujo and Blanca Rosa Blanco, Ministerio de Cultura de Cuba, Instituto Cubano de Radio y Televisión (ICRT) and ICAIC, 2011.

Jameson, Fredric. "Third-World Literature in the Era of Multinational Capitalism." Social Text, 1986, pp. 65-88, www.jstor.or/stable/466493.

Mañach, Jorge. Marti: The Apostle of Freedom. Devin-Adair, 1950.

Martí, José. La Edad de Oro. 1889, Editorial Gente Nueva, 1979.

- Versos sencillos / Simple Verses. Translated with introduction by Manuel A. Tellechea, Arte Público P, U of Houston, 1997.

Oxford Dictionary, www.en.oxforddictionaries.com/definition/radicant. 